\title{
Interaction between Soil Physicochemical Parameters and Earthworm Communities in Irrigated Areas with Natural Water and Wastewaters
}

\author{
Kourtel Ghanem Nadra,, ${ }^{1,2}$ Kribaa Mohammed, ${ }^{3}$ and El Hadef El Okki Mohammed ${ }^{4}$ \\ ${ }^{1}$ Agronomic Sciences Department, Veterinary Sciences and Agronomic Sciences Institute, Batna 1 University, 05000 Batna, Algeria \\ ${ }^{2}$ Ecology and Environment Department, Faculty of Life and Natural Science, Batna 2 University, Fisdis, Batna, Algeria \\ ${ }^{3}$ Biology Departement, Université Larbi Ben M’hidi Oum El Bouaghi, 04000 Oum El Bouaghi, Algeria \\ ${ }^{4}$ Institut National de l'Alimentation, Université des Frères Mentouri de Constantine 1, Constantine, Algeria \\ Correspondence should be addressed to Kourtel Ghanem Nadra; nadra_gh@yahoo.fr
}

Received 6 March 2017; Revised 14 June 2017; Accepted 31 July 2017; Published 11 October 2017

Academic Editor: Marco Trevisan

Copyright (C) 2017 Kourtel Ghanem Nadra et al. This is an open access article distributed under the Creative Commons Attribution License, which permits unrestricted use, distribution, and reproduction in any medium, provided the original work is properly cited.

\begin{abstract}
Our objective is to study interaction between physical and chemical properties of soils and their earthworm community characteristics in different areas irrigated by wastewaters and well waters. The fields have different topography and agricultural practices conditions and are located in two regions of Batna department (Eastern Algeria). Both regions are characterized by a semiarid climate with cold winters and Calcisol soils. Nine fields were subject of this study. Three of these fields are located in Ouled Si Slimane region whose irrigation is effectuated by natural waters of Kochbi effluent. The other six fields are located at edges of Wed El Gourzi, effluent from Batna city, and partially treated through water treatment station. The best rates of water saturation and infiltration as well as abundance of earthworms were recorded at sites characterized by irrigation with wastewaters downstream of El Gourzi effluent. PCA characterizes two major groups: a group of hydrodynamic infiltration parameters and structural index stability of soil, explained by fields irrigated with wastewaters downstream of El Gourzi effluent. This group includes chemical characteristics: $\mathrm{pH}$ and electric conductivity. The second group is the characteristics of earthworms and includes organic matter content, active limestone levels, and Shannon Biodiversity Index.
\end{abstract}

\section{Introduction}

Treated or untreated urban wastewater has been used commonly for agricultural irrigation in arid and semiarid regions of the world. According to the estimations, at least 20 million hectares of agricultural land worldwide is irrigated with treated and untreated wastewaters [1]. In areas suffering from water shortage, such as arid and semiarid areas, where insufficiency and water scarcity inevitably pose problems, especially from the point of view of meeting quantitative needs of irrigation in agriculture, the wastewater recycling as a complementary water resource is interesting for cultivated soils to solve the problem posed in agriculture by water resources insufficiency in these zones [2]. Its use has increased recently because there are inadequate freshwater resources. The population suffering from water scarcity is presently $11 \%$ of the total worldwide population; it is estimated that the population with adequate water will be $38 \%$ in 2025 [3].

Reuse of raw or treated agricultural wastewater is a widespread practice downstream of urban centers and mostly in areas affected by water shortages [4]. Although proscribed, this practice is appreciated by farmers because wastewater is a regularly available and abundant resource and contains the fertilizer needed to improve soil properties and yield crops $[5,6]$.

Urban wastewater contains higher levels of organic matter, nutrients, and pollutants (heavy metals and suspended solids) compared to fresh water. Although wastewater application provides positive effects on soil properties and crop productivity because of its high organic matter and macroand micronutrient contents, the pollutants in wastewater may 
cause some problems to soil and crops [7]. Nevertheless, wastewater compounds in particular affect soil porosity and hence hydrological properties [8]. Nadav et al. [9] indicated that the physicochemical properties of soils were altered with treated wastewater irrigation, because long-term wastewater application caused the accumulation of organic matter in soil. High organic matter in wastewater is cement for the improvement of soil aggregates. Therefore, lower bulk density and higher infiltration and water retention have been obtained under the wastewater irrigation conditions. However, suspended solids in wastewater negatively affect the soil porosity.

Earthworm's activities of a mechanical or metabolic nature allow transforming organic matter, recycling nutrients, and transferring matter and energy between different horizons. Their importance in mixing soil horizons has been underlined by many authors [10-13]. Earthworms have a very important role for soil fertility; they essentially favor the formation of clay-humic complexes; anecic worms together feed on organic and mineral matter, increase stability of aggregates, and make it possible to unpack compacted soils [14]. Above all, they create loose structure elements in soil, possessing high porosity, which increases useful reserves and allows good aeration; this structure is very favorable to germination and nodulation of clover and increases yield of certain crops [15]. Roots use earthworm galleries to grow [14]. Earthworms also modify the microbial communities through digestion, stimulation, and dispersion in casts. Consequently, changes in activities of earthworm communities, as a result of soil management practices, can also be used as indicators of soil fertility and quality [16]. Despite the importance of this fauna and work done on these organisms, it is not important in Algeria [17]. In Algeria, work on biodiversity of earthworms is still insufficient. This very varied biogeographic space in terms of climate, soil, and vegetation from the littoral to the desert could reveal a great diversity of earthworms with certainly species very adapted to the drought. Studies on this subject are difficult: on one hand, identification and classification of these organisms remain difficult due to lack of qualified taxonomists [18] and, on the other hand, study of earthworms is not obvious due to several constraints related to nature of soil and the complexity of these organisms [19].

In this complex set of contexts, we have found it interesting to contribute to studying the interaction between physical and physicochemical properties of soil and the properties of earthworm community in El Madher region, where soils are cultivated and irrigated by the partially treated waters of El Gourzi effluent and are in incessant extension. We have chosen Ouled Si Slimane area as a control field, which is irrigated by water from natural sources. El Madher and Ouled Si Slimane areas are located in Batna department, characterized by a semiarid climate with cold winters and Calcisol soils according to WRB in 1999.

\section{Materials and Methods}

2.1. Presentation of El Madher Region. El Madher town is located in the northeast part of Batna department at a distance of $23 \mathrm{~km}$ from Batna town (Figure 1). The geographical coordinates of this region are as follows: latitude: $35^{\circ} 37^{\prime} 52^{\prime \prime}$; Longitude: $6^{\circ} 22^{\prime} 09^{\prime \prime}$. It is at an altitude of 1100 meters.

The geomorphology of this region is related to brittle tectonics, where a collapse zone corresponds to a plain and a high zone corresponds to the mounts: Dj. Bou Arif (1744 m), Koudiat Tfouda in Dj. Tafraout $(1080 \mathrm{~m})$, and Dj. Sarif $(1744 \mathrm{~m})$. The hydrographic network is mainly represented by Gourzi effluent or El Madher river, which springs from Batna watershed and empties into the Chott Gadine, with a multitude of Chaabas and Talwegs.

Precipitation is very low distributed over a period of 30 years (1985-2015), with total annual average precipitation of $319,28 \mathrm{~mm} /$ year. The average monthly temperature range is from $5.23^{\circ} \mathrm{C}$ in January to $25.66^{\circ} \mathrm{C}$ in July. The Gaussen Ombrothermic diagram shows a relatively long dry period, spreading from May to October. The study area is classified according to Emberger's Climogram in semiarid bioclimatic zone with cool winter and hot summer.

2.2. Presentation of Ouled Si Slimane Region. Ouled Si Slimane town is located in the western part of Batna department at a distance of $90 \mathrm{~km}$ (Figure 1). The chief town of Daïra is limited by the following Lambert coordinates: $35^{\circ} 37^{\prime} \mathrm{N}$ for latitude North and $5^{\circ} 38^{\prime}$ for longitude East, with an average altitude of $760 \mathrm{~m}$.

The main geological structure of Ouled Si Slimane region is divided into three strata as follows:

(i) The mountainous region consists mainly of calcareous rocks of the Cretaceous.

(ii) The plains consist mainly of calcareous marls of lower Miocene.

(iii) There are also slopes and Wadis (rivers or effluents). Those are alluviums, regs, and terraces of the Quaternary constituted principally of clays, silt, and pebbles.

Hydrography is represented by an effluents network all oriented from north to south and from north to east of the region. This network is practically seasonal, dry in summer and torrential in winter. It includes Wed Laïoune and Wed Kochbi effluents.

Precipitation is very low distributed over a period of 25 years, with total annual average precipitation of $318,12 \mathrm{~mm} /$ year. The Gaussen Ombrothermic diagram shows a relatively long dry period, spreading from May to October. The study area is classified according to Emberger's Climogram in semiarid bioclimatic zone with cold winter and hot summer.

2.3. Selection and Description of Sampling Sites. We selected in our first study area six different sites with different peculiarities of topography (upstream and downstream), vegetation, agricultural practice, and irrigation by wastewaters from El Gourzi effluent for more than 10 years. These sites are distributed along the effluent upstream at an altitude of $924 \mathrm{~m}$ to downstream at an altitude of $868 \mathrm{~m}$ for a distance of about $25 \mathrm{~km}$. El Gourzi effluent is the main collector of sewage network of the city of Batna as well as rainwater. It is an open effluent that crosses this town, with a flow that varies 


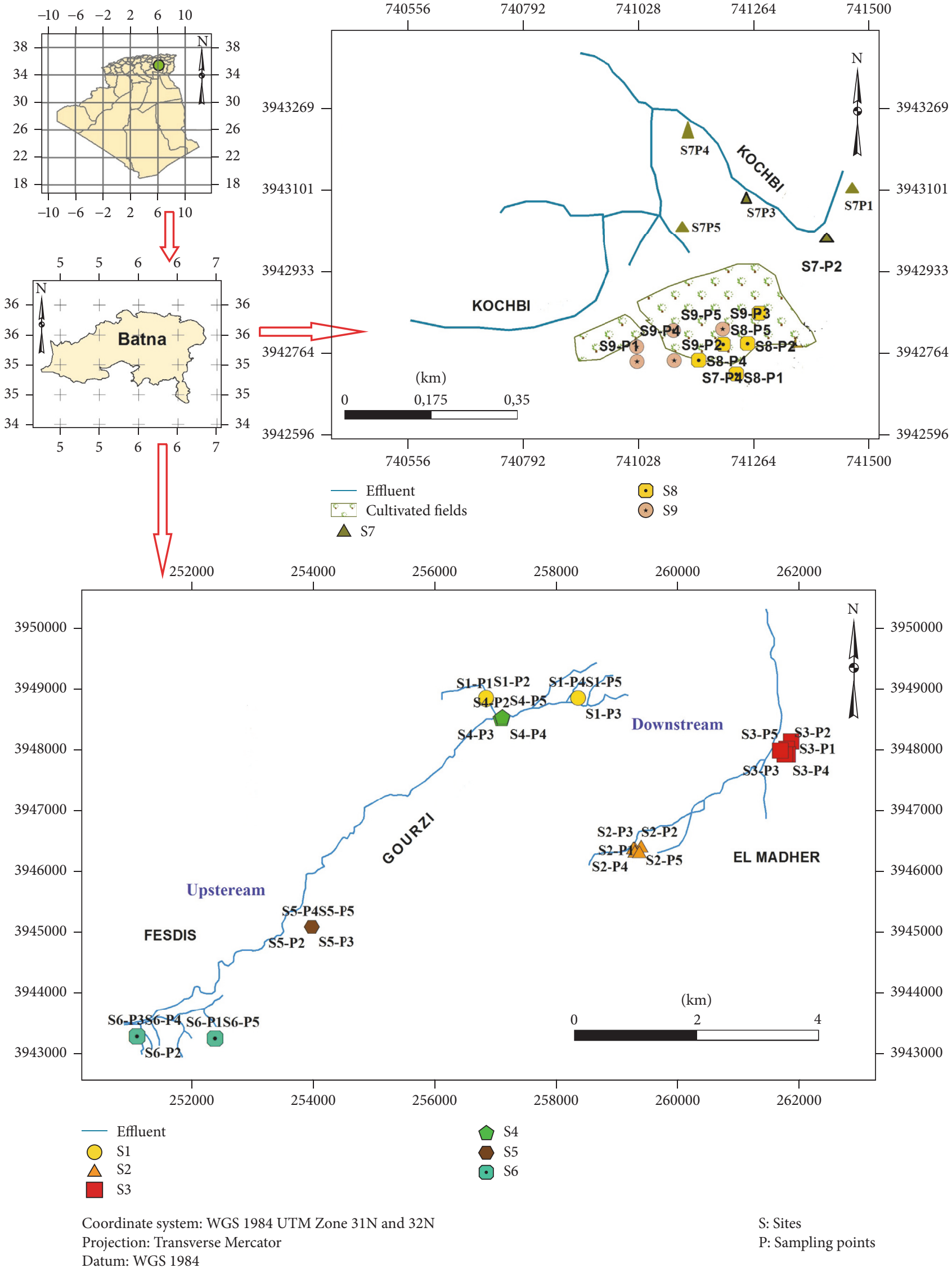

FIGURE 1: Maps of localisation of study area and sampling sites at edges of El Gourzi and El Kochbi effluents. 
TABLE 1: Average values of physicochemical characteristics of El Gourzi effluent wastewaters in 5 different upstream to downstream points [15].

\begin{tabular}{lcccccc}
\hline Sites & $T^{\circ} \mathrm{C}$ & $\mathrm{pH}$ & $\mathrm{EC}(\mathrm{dS} / \mathrm{m})$ & $\mathrm{MES}(\mathrm{mg} / \mathrm{l})$ & $\mathrm{BOD} \mathrm{mg}\left(\mathrm{d} \mathrm{O}_{2} / \mathrm{l}\right)$ & $\mathrm{COD} \mathrm{mg}\left(\mathrm{d} \mathrm{O}_{2} / 100 \mathrm{ml}\right)$ \\
\hline 1 & 13,1 & 8,66 & 2200 & 480,25 & 264,4 & 398,2 \\
2 & 13,5 & 8,32 & 2750 & 530,03 & 224,28 & 357,6 \\
3 & 13,4 & 8,21 & 2700 & 552,26 & 426,74 & 597,3 \\
4 & 13,1 & 7,82 & 2390 & 525,09 & 264,18 & 503,4 \\
5 & 12,9 & 7,55 & 1880 & 449,21 & 157,78 & 270,7 \\
\hline
\end{tabular}

EC: electric conductivity; MES: suspended matter; BOD5: 5-day biological oxygen demand; COD: chemical oxygen demand.

TABLE 2: Range of nitrogen, phosphorus, heavy metals (ETM), and pathogens contents from 7 upstream to downstream wastewater sampling points in El Gourzi effluent, according to Tamrabet et al.s [20] study.

\begin{tabular}{lcccccccccc}
\hline Parameter & $\begin{array}{c}\mathrm{NO}^{3-} \\
\mathrm{mg} / \mathrm{l}\end{array}$ & $\begin{array}{c}\mathrm{NH}^{4+} \\
\mathrm{mg} / \mathrm{l}\end{array}$ & $\begin{array}{c}\mathrm{PO}_{4}{ }^{3-} \\
\mathrm{mg} / \mathrm{l}\end{array}$ & $\begin{array}{c}\mathrm{Fe} \\
\mathrm{mg} / \mathrm{l}\end{array}$ & $\begin{array}{c}\mathrm{Mn} \\
\mathrm{mg} / \mathrm{l}\end{array}$ & $\begin{array}{c}\mathrm{Cu} \\
\mathrm{mg} / \mathrm{l}\end{array}$ & $\begin{array}{c}\mathrm{Mn} \\
\mathrm{mg} / \mathrm{l}\end{array}$ & $\begin{array}{c}\mathrm{Zn} \\
\mathrm{mg} / 1\end{array}$ & $\begin{array}{c}\mathrm{FC} \\
\mathrm{G} / 100 \mathrm{ml}\end{array}$ & $\begin{array}{c}\mathrm{FS} \\
\mathrm{G} / 100 \mathrm{ml}\end{array}$ \\
\hline \multirow{2}{*}{ Range values } & $3.25-6.4$ & $58.5-170.7$ & $1.4-13.45$ & $0.14-4.08$ & $5.14-9.1$ & $0.60-0.66$ & $5.14-9.1$ & $\begin{array}{c}0.28-0.74 \\
0.70^{4}-2.75 \times \\
10^{4}-1.1 \times \\
10^{4}\end{array}$ \\
\hline
\end{tabular}

$\mathrm{NO}^{3-}$ : nitrates; $\mathrm{NH}^{4+}$ : ammonium; $\mathrm{PO}_{4}{ }^{3-}$ : orthophosphates; Fe: iron; Cu: copper; $\mathrm{Zn}$ : zinc; $\mathrm{Mn}$ : manganese; FC: fecal coliforms; FS: fecal streptococci; G: germs/seeds.

according to seasons. Before leaving the city, it passes through industrial zone, where it collects, in addition to urban waste, all industrial waste [20]. Only a part of these discharges $\left(15,000-2,000 \mathrm{~m}^{3}\right.$ per day) are treated in treatment station before joining the effluent [21].

Maalem et Ghanem [22] studied the water quality of El Gourzi effluent at 5 upstream to downstream points; he showed that these wastewaters are characterized by higher values of $\mathrm{pH}, \mathrm{EC}, \mathrm{MES}, \mathrm{BOD} 5$, and COD upstream than downstream (Table 1). This was also proven in the study of Tamrabet et al. [20]. According to the same study [20] (Table 2), this effluent is generally more charged upstream than downstream by nitrates, ammonium, orthophosphates, iron, copper, zinc, manganese, fecal coliforms, and fecal Streptococcus. The process of evolution from upstream to downstream direction acts by current force on water flow itself on suspended matter flow, mineral and organic matter, and that of living organisms [23]. In conditions of our study area, problems of phytotoxicity by Trace Element Metals do not arise for the moment because of their low content on one side and physicochemical characteristics of soil on the other side. The soil of El Madher region is of clay loam nature; according to Marschner [24], these conditions favor the precipitation of TEM. However, Alouni [25] mentions that the epidemiological risks of pathogens such as Salmonella and Vibrio cholerae are zero. Only the risks related to fecal coliforms and fecal streptococci are latent in wastewaters.

Three other sites in second studied area are irrigated with healthy potable and unpolluted waters from Kochbi and differ only in conditions of vegetation and cultural practices. El Kochbi is the effluent from natural water source of Kochbi. These sites are distributed in two localities of Guerza and Teniet El Abed at an altitude oscillating between 780 and $849 \mathrm{~m}$ for a distance of about $20 \mathrm{~km}$.
The sites are all characterized by fine granulometric size textures (Table 3 ). The sites are characterized by their cultural practices (cereal cultivation and arboriculture) and tillage; irrigation takes place according to climatic demands of crops. The input of fertilizers is made as basic fertilizer every two years generally with plowing, in form of NPK. The sites chosen as control are the borders of effluent under natural vegetation and without any practice; they are influenced by their proximity to effluents and are wet by capillary ascension. We carried out 5 sampling points of soil and earthworms in each of the sites. In total, 45 points were studied (Table 4) in 2014, 2015, and 2016 in spring period of March, April, and May. This period is the most suitable for removing earthworms because the soil is moist, and spring temperatures favor worm activity.

2.4. Methods Sampling. The method used is manual sorting [10-12]. It is a physical method of extracting earthworms. Each sampling point consists of a single sample using a shovel with a volume of soil of $30 \times 30 \times 30 \mathrm{~cm}$. Worms were collected at the same time as soil and stored in vials with $4 \%$ formalin. Soil sampling was carried out after sorting the earthworms and deposited in labeled and numbered polyethylene bags and taken to the laboratory.

2.5. Methods of Soil Physical Properties Analysis. Determination of different particle size soil fractions was performed after organic matter destruction and particles dispersion; the clay, the fine loam, and the coarse silt content were estimated by Robinson pipette, fine sand, and coarse sand by sieving.

Soil moisture at time of earthworms' removal was determined after passing in oven set at $105^{\circ} \mathrm{C}$ of a soil moist weight 
TABLE 3: Textural classification of soils from sampling sites in El Madher and Ouled Si Slimane areas.

\begin{tabular}{lccccccccc}
\hline Sites & S1 & S2 & S3 & S4 & S5 & S6 & S7 & S8 & S9 \\
\hline \% sand & 14,20 & 19,96 & 45,77 & 32,63 & 29,82 & 32,93 & 46,24 & 30,58 & 25,44 \\
\% silt & 33,02 & 42,28 & 15,05 & 35,12 & 30,75 & 42,11 & 32,05 & 65,73 & 67,07 \\
\% clay & 52,78 & 37,76 & 39,19 & 32,25 & 39,42 & 24,96 & 21,71 & 3,69 & 7,49 \\
Textural class & Clay & Clay loam & Clay loam & Clay loam & Clay & Loam & Loam & Silt loam & Silt loam \\
\hline
\end{tabular}

TABLE 4: Cropping practices characteristics in the selected sites at El Madher and Ouled Si Slimane areas.

\begin{tabular}{|c|c|c|c|c|c|}
\hline Station & Cropping practices & Topography & Mean altitude $(\mathrm{m})$ & Water irrigation quality & Year of study \\
\hline S1 & El Gourzi effluent edges & Downstream & 864,0 & Wastewaters & 2016 \\
\hline S2 & Arboriculture (olive tree) & Downstream & 862,4 & Wastewaters & 2016 \\
\hline S3 & Cereal farming (barley/corn/wheat) & Downstream & 853,8 & Wastewaters & 2016 \\
\hline S4 & El Gourzi effluent edges & Upstream & 874,8 & Wastewaters & 2015 \\
\hline S5 & Cereal crops (wheat/alfalfa) & Upstream & 903,4 & Wastewaters & 2015 \\
\hline S6 & Market gardening/cereal farming & Upstream & 923,4 & Wastewaters & 2015 \\
\hline S7 & El Kochbi effluent edges & Downstream & 808,4 & Natural waters & 2014 \\
\hline S8 & Arboriculture (olive tree) & Upstream & 786 & Natural waters & 2014 \\
\hline S9 & Cereal farming (wheat/barley) & Downstream & 779,4 & Natural waters & 2014 \\
\hline
\end{tabular}

for 24 hours. It is estimated by the following formula:

$$
H \%=\frac{W_{m}-W_{d}}{W_{d}} \times 100 .
$$

$H \%$ is the soil moisture at time of earthworms removal; $W_{m}$ is soil moist weight; $W_{d}$ is soil dry weight.

Soil moisture at maximum retention capacity $(\mathrm{Cr} \%)$ was estimated by submersion of soil samples by water until saturation. Steaming is at $105^{\circ} \mathrm{C}$.

The method measuring soil bulk density $\left(\mathrm{Da}, \mathrm{g} / \mathrm{cm}^{3}\right)$ consisted in using metal cylinders of known volume $\left(126,60 \mathrm{~cm}^{3}\right)$. Porosity $(P \%)$ was calculated by bulk density measurements and soil real density of $2.65 \mathrm{~g} / \mathrm{cm}^{3}$.

Hénin's structural instability index (IS) according to Mussy and Soutter [26] is by definition proportional to soil sensitivity phenomena of bursting on one side and of swelling dispersion on the other. Three samples of $10 \mathrm{~g}$ of a soil sample of $300 \mathrm{~g}$ are taken without the destruction of the organic matter, previously sieved to dryness at $2 \mathrm{~mm}$. Two of them are, respectively, treated with $5 \mathrm{~cm}^{3}$ of alcohol at $95^{\circ}$ and $5 \mathrm{~cm}^{3}$ of benzene. After 5 minutes of imbibition, the three samples are suddenly immersed in water and then after half an hour of contact sieved to $0.2 \mathrm{~mm}$, which makes it possible to determine the terms $\mathrm{AgA}, \mathrm{AgB}$, and $\mathrm{AgE}$. IS was expressed by the following relation:

$$
I S=\frac{\text { Fraction } \varnothing<0,02 \mathrm{~mm}(\max )}{(\operatorname{AgA}+\mathrm{AgB}+\mathrm{AgE}) / 3-0,9 \mathrm{Sg}},
$$

where AgA, AgB, and AgE are fractions determined by weight which are collected after sieving with a tamis of $0,2 \mathrm{~mm}$. These fractions remain after immersion in, respectively, alcohol, benzene, and water. Sg is a fraction of sand included in AgA, $\mathrm{AgB}$, and AgE fractions.

The filtration rate $K(\mathrm{~h})$ at saturation was estimated from Darcy's sense by the method of a soil maintained in a permanent water flow. $K(\mathrm{~h})$ was carried out by open PVC cylindrical tube at both ends, having a diameter of $9 \mathrm{~cm}$ and a height of $40 \mathrm{~cm}$, and is gently pressed into soil layer and carefully removed without being disturbed. A piece of tulle is put on using an elastic ring at the bottom of the tube. Water soil infiltrating in a beaker is collected every 5 minutes in a test tube to determine volume. This happens until reaching a constant volume during 1 hour. $K(\mathrm{~h})$ sat. $(\mathrm{mm} / \mathrm{h})$ is determined for the water heights of $0.05,0.3,0.6$, and $1 \mathrm{kPa}$ and calculated by (3) of Darcy law cited by Mussy and Soutter [26].

$$
K\left(\mathrm{~cm} \cdot \mathrm{h}^{-1}\right)=\frac{E \cdot V}{H \cdot S}
$$

where $E$ is height of soil column by $\mathrm{cm} ; V$ is percolated water for 1 hour of infiltration by $\mathrm{cm}^{3}$; $H$ is height of water column by $\mathrm{cm} ; S$ is internal section of tube by $\mathrm{cm}^{2}$.

2.6. Methods of Soils Chemical Properties Analysis. The $\mathrm{pH}$ and electrical conductivity (EC) were measured by direct reading on a $\mathrm{pH}$ meter and conductivity meter in a suspension with a soil/water ratio of $1: 2.5$ and $1: 5$, respectively [27].

Determination of organic matter content (OM\%) is performed using the Walkley and Black method, which is based on the oxidation of carbon with potassium dichromate in strongly acid media [28]. 
Total $\mathrm{CaCO}_{3} \%$ is determined by volumetric method of the "Bernard Calcimeter," while active $\mathrm{CaCO}_{3} \%$ is determined by contact with a specific extraction reagent, "ammonium oxalate," at $0.2 \mathrm{~N}$.

2.7. Methods Studying Earthworms. The determination of taxa concerns only adult worms. In this study, we tried to use much more external characters of worms collected using internal anatomical features for certain taxa to determine species in question. The external and internal characters used are those explained by Bouché and Bachelier $[10,11]$. The key chosen for taxa determination is modified by Blakemore in 2007 [29]. For classification of ecological categories, we used that of Bouché $[10,30]$ which was used by Bazri [31] in his study of the Northern Algerian earthworm population.

Abundance is expressed as point abundance, that is, total number of earthworms present in a sampling point, and is expressed as number of individuals per $\mathrm{m}^{2}$.

Earthworm biomass is expressed as population biomass taken and expressed by individual biomass (weight of each worm) and worm point biomass (total weight of worms taken at a sampling point).

To estimate diversity of earthworm community for each site, we used Shannon diversity index derived from a function established by Shannon and Wiener which became the Shannon diversity index.

Value of Shannon diversity index $H^{\prime}$ varies between 0.5 and 4.5 bits and is given by the following formula [32, 33]:

$$
H^{\prime}=-\sum \mathrm{Pi} \log _{2} \mathrm{Pi}
$$

where $\mathrm{Pi}$ (see (5)) is number of species $i$ individuals in relation to total number of individuals identified $(N)$ :

$$
\mathrm{Pi}=\frac{\mathrm{ni}}{N}
$$

This index is independent of sample size and takes into account distribution of individuals number per species [34].

\section{Results and Discussion}

\subsection{Soil Compartment}

3.1.1. Physical Properties of Soil. The means of soil moisture $(\mathrm{H} \%)$ at moment of sampling of earthworm are in Table 5. These close rates of soil moisture among the nine sites seem to be more favorable to the biological activity of earthworms. These moisture levels are due to spring irrigation or precipitation. Average of highest water retention rate $(\mathrm{Cr} \%)$ was recorded at S1, S4, and S7 at border of effluents. Overall, mean water retention rates in study sites appear to be closely related to fine particle contents of study fields, especially at the edges of effluents downstream, where they are deposited after training by the flow of water. Meanwhile, Mojid and Wyseure [35] determined enhanced water retention capacity values in the wastewater irrigation conditions compared to fresh water irrigation.

Porosity is highest in S2 characterized by wastewaters downstream and by cereal crops, while it was lowest at

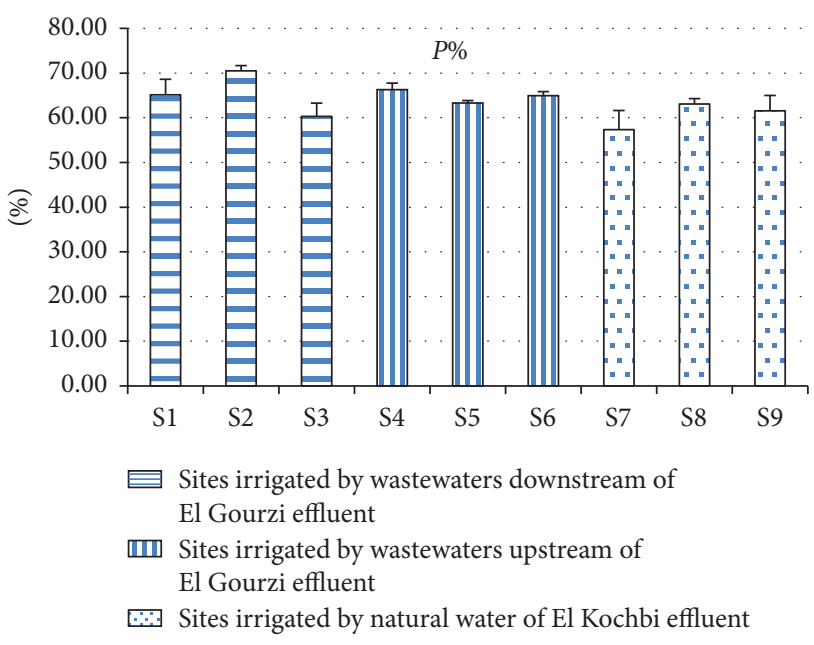

FIGURE 2: Total porosity average in study sites.

S7 at edges of natural water Kochbi effluent (Figure 2). Effectively, Gharaibeh et al. [36] noted that irrigation treated for long periods with wastewaters resulted in slight decrease in bulk density compared to the control. Many researches obtained lower bulk density or higher porosity values under wastewater irrigation [35, 37, 38]. Moreover, elevation of dissolved organic matter in treated wastewaters is reported to cause/increase clay dispersion by reducing the differential viscosity of clay suspensions and decreasing the attraction forces between clay particles [39]. Wang et al. [40] indicated that wastewater irrigation caused a slight increase in soil compaction. Particularly high-suspended solid concentration in wastewater may increase the bulk density, while lower concentrations may not significantly affect it [41]. These values reflect, on one hand, the plowing practices in the study sites and, on the other hand, a less favorable effect of the accumulation of organic matter in the fields located upstream of the effluent.

Structural stability is better in S6 characterized by irrigation with wastewaters upstream and alternations of vegetable crops and cereal crops (Figure 3). It is low in S8 with irrigation by natural waters and arboriculture. Indeed, Kirkham [42] notes that inputs of sludge in successive 4 years have raised organic matter content of soil of the first $15 \mathrm{~cm}$ from 1.2 to $2.4 \%$. Input of organic matter and calcium ions play a favorable role in cements stability, which causes improvement of soil particles. This same author underlined an improvement of unfavorable structures for clayey soils following application of sludge. Also, Gharaibeh et al. [36] noticed that aggregate stability (AS\%) results revealed that irrigation with treated wastewaters significantly increased the percentage of stable soil aggregates compared to the control. Miller and Kemper [43] observed increases in water-stable aggregates at least for one growing season following alfalfa incorporation, after which there was a decrease. They attributed this increase to the production of cementing substances through microbial activity by fungal and actinomycete mycelia which provides substrates to stabilize soil aggregates. However, Vogeler [38] 


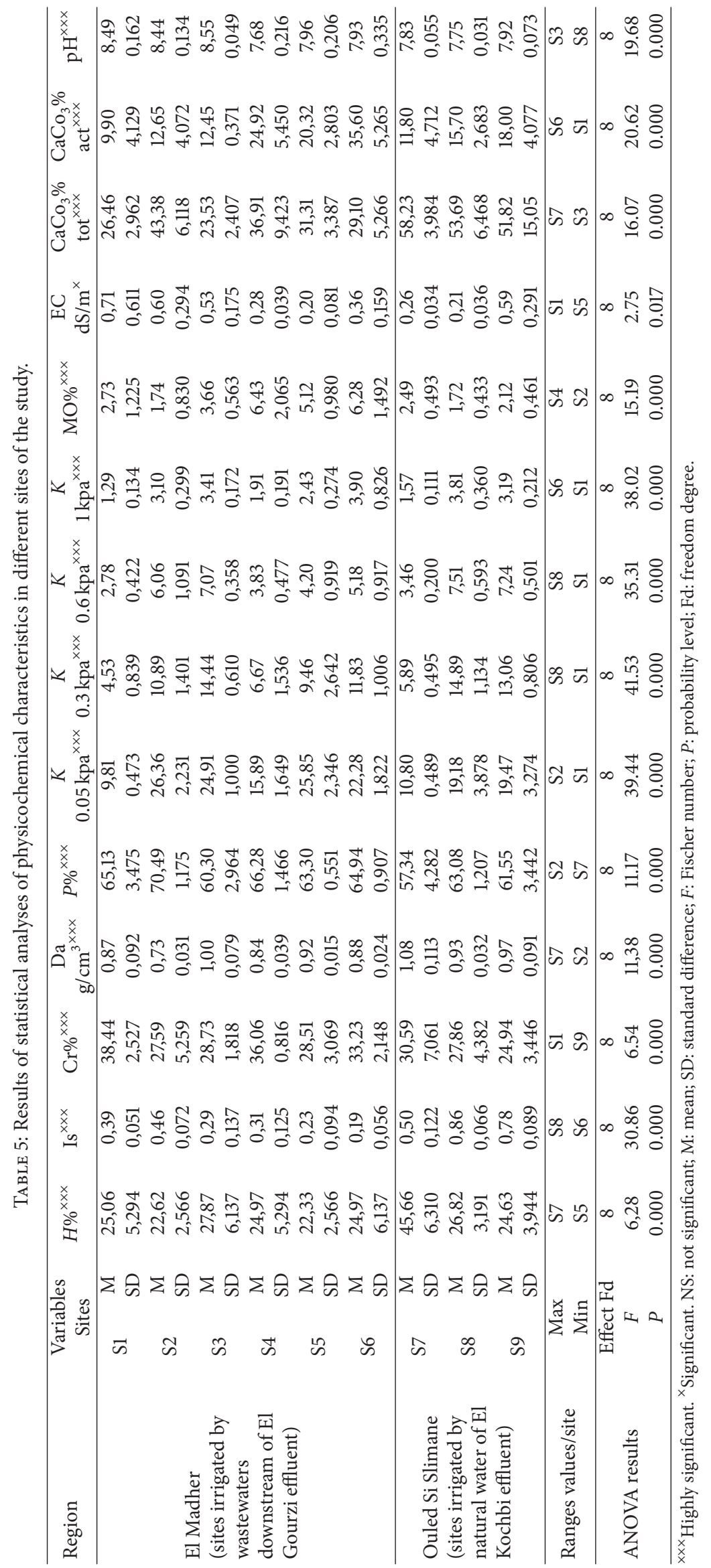




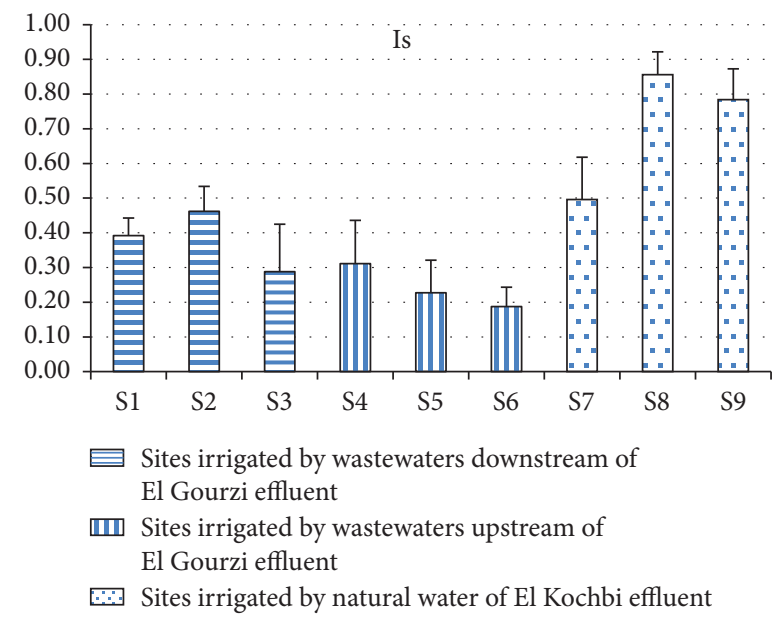

FIgURE 3: Average of Hénin's structural stability index in study sites.

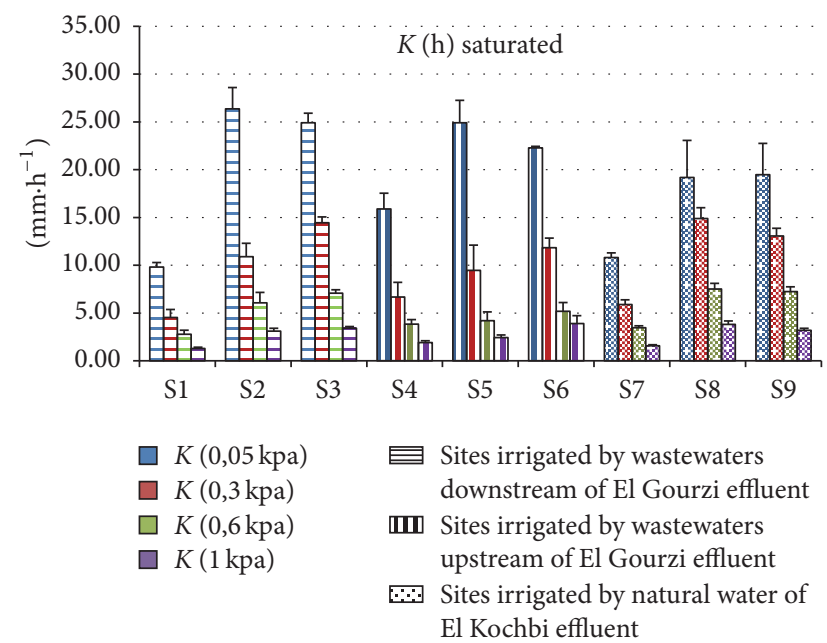

FIGURE 4: Saturated hydraulic conductivity average at different water potential in study sites.

attributed higher AS value to the higher total carbon content or to the composition of soil organic matter in areas irrigated for long periods with treated wastewaters compared with the control block.

The best rates of filtration at saturation $K \mathrm{~s}(\mathrm{~h})$ for $0,05 \mathrm{kPa}$ suction were recorded in S2 and S3 sites characterized by wastewaters downstream of El Gourzi effluent (Figure 4). But globally for this pressure, $K s$ is more important in the irrigated wastewaters. For the other pressures, difference is less remarkable. Rapid infiltration capacity of a soil is estimated by macroporosity. Rabbi et al. [44] mention that percentages of clay, bulk density, and porosity have a strong influence on Ks. These results are in agreement with Bardhan et al. [45] who reported a decrease in the infiltration rate due to clogging of soil pores by suspended materials present in the treated wastewaters. Previous studies with similar soil texture (clay) of the current study reached the same conclusion that application of wastewater resulted in pore clogging, which leads to reduced soil porosity and subsequently a decrease in the soil infiltrability [46].

Meanwhile, Morel et al. [47] showed that permeability of a soil increases significantly in plots enriched with sludge, as organic matter richness of sludge improves water balance and increases reserve of useful water; this favors processes of stabilization of soil aggregates and in particular gives soil a better permeability in relation to a more stable structure. There is a close relationship between the pore size distribution and soil water content due to the fact that macropores control the aeration and drainage, mesopores control the water conductivity, micropores control the water retention and the most available water for plants [48].

3.1.2. Chemical Soil Properties. The pH (Table 5) in study fields shows moderate alkalinity in sites irrigated with natural waters, as well as fields irrigated by wastewater upstream. The $\mathrm{pH}$ levels are more alkaline in sites downstream of wastewater effluent than in the sites with upstream wastewaters. Standard deviations between $\mathrm{pH}$ values of sampling points of sites often irrigated by upstream wastewater are much greater. Schipper et al. [15] indicate that soil $\mathrm{pH}$ increases as a result of a long period of irrigation with wastewater. They attribute this increase to chemical composition of cations effluent such as $\mathrm{Na}, \mathrm{Ca}$, and $\mathrm{Mg}$. The $\mathrm{pH}$ of soil irrigated with wastewater decreases following oxidation of organic compounds and nitrification of ammonium [49-51].

Electrical conductivity values are the lowest at sampling points of S5, characterized by irrigation by wastewater upstream of El Gourzi effluent. Standard deviation values are much higher at sampling points of S1, as previously described. Contrary to the results mentioned in the work of Maalem and Ghanem [22] on the values of El Gourzi effluent's wastewaters, which are higher upstream than downstream, the soil has higher CE values downstream than upstream. This could be due to the organic matter, which acts as a buffer. In a general way, according to standards presented by DIAEA/DRHA/SEEN in El Oumlouki et al. [52], EC of various treatments soils of our experimentation remains weak.

The organic matter is lowest at S8 with well water irrigation and arboriculture (Figure 5). It is highest at S4 upstream of El Gourzi effluent border. Indeed, Tamrabet et al. [6] reported that a comparison of control soil averages and irrigated soils by wastewater shows that irrigation with this wastewater has a very significant effect on OM improvement. However, many other studies showed increase in the OM\% within creased period of treated wastewaters irrigation [38, 53, 54]. This is the case in our study. Moreover, high clay content of soil may physically protect the OM from the decomposition.

The average percentage rate of total $\mathrm{CaCO}_{3} \%$ is lowest at S3 downstream of El Gourzi effluent. It is highest at Kochbi natural water effluent border. These values are generally strongly to very strongly calcareous according to grading scale proposed by GEPPA in Baize [27]. The limestone levels appear to be related to soil $\mathrm{pH}$. 


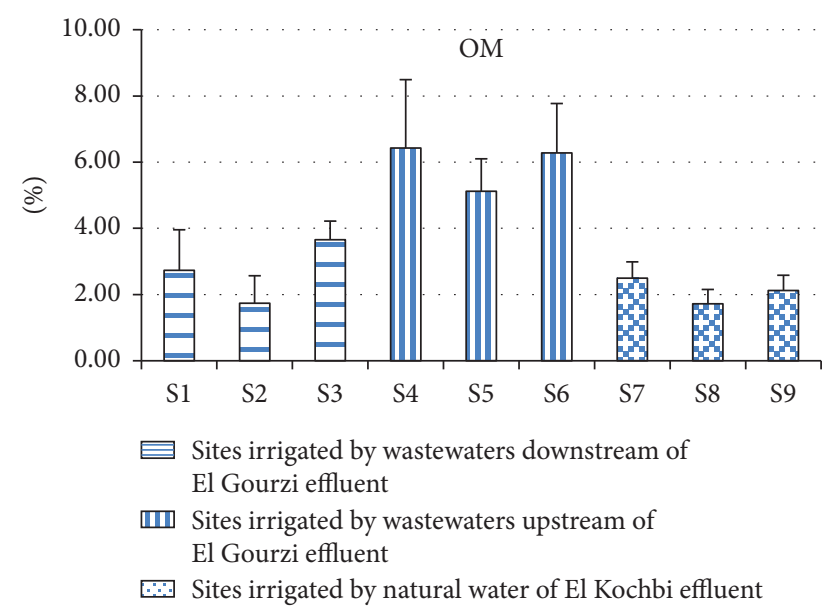

FIGURE 5: Organic matter rate percentage average in study sites.

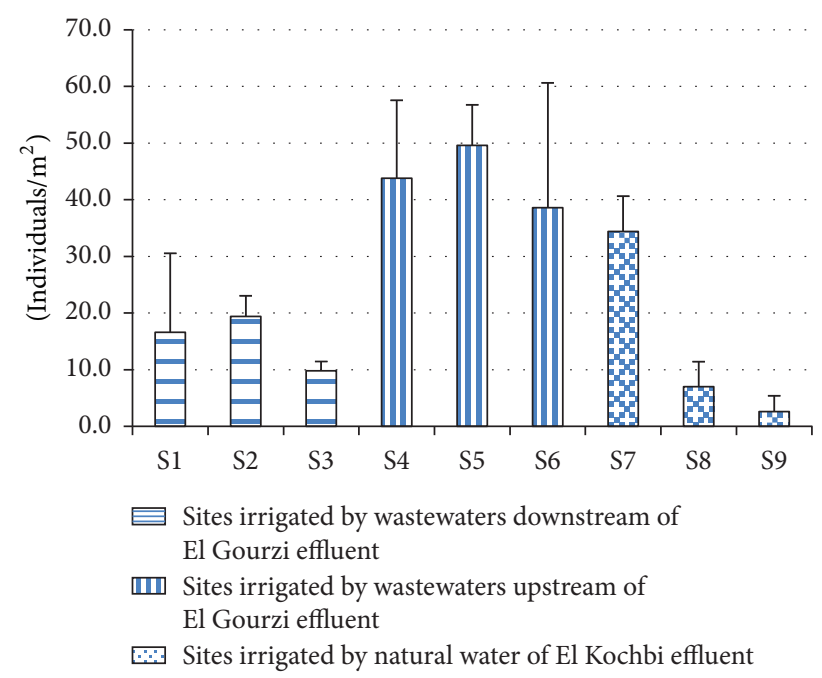

FIGURE 6: Earthworms' total abundance in different sites of study.

3.2. Earthworm Compartment (Table 6). The total abundance and biomass average of earthworms at different sampling points of study sites are the lowest in S9 with irrigation by natural waters of El Kochbi effluent and cereal crop. They were the highest in S5 with irrigation by El Gourzi wastewater upstream and cereal growing (Figure 6). This abundance was represented by $54 \%$ of adults and $46 \%$ of juvenile worms (Figure 7). Our results explain a negative effect of plowing on the abundance and biomass of earthworms. Contrariwise, the irrigation with wastewaters improves significantly their abundance and biomass. In Bazri et al.s [17] study, the density of earthworm in eastern Algeria from the coast to the desert was, respectively, $6.00 \pm 1.41$ to $29.60 \pm 11.83$ individuals $/ \mathrm{m}^{2}$ and $0.28 \pm 0.39$ to $13.13 \pm 7.94 \mathrm{~g} / \mathrm{m}^{2}$. These results are almost similar to those of Omodeo and Martinucci [55] in Northern Algeria who found earthworm densities ranging from 11.0 to 12.7 individuals $/ \mathrm{m}^{2}$ and biomass ranging from 1.25 to $3.0 \mathrm{~g} / \mathrm{m}^{2}$. Edwards and Bohlen [56] explained that soils with

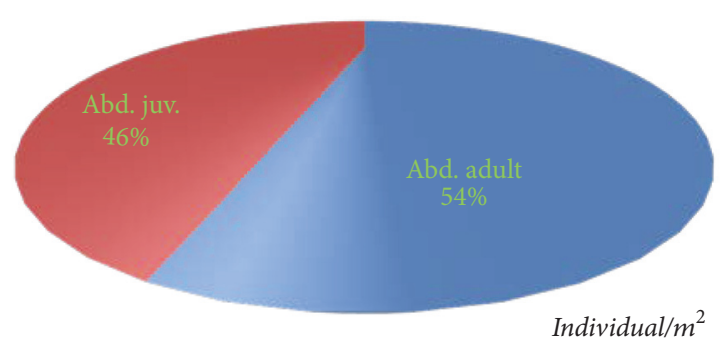

FIGURE 7: Total abundance percentage of earthworms in study sites.

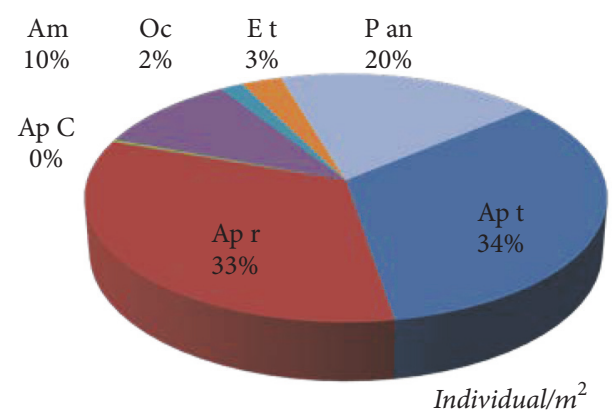

FIGURE 8: Earthworms' global specific abundance percentage.

low organic matter contents usually do not support high densities of earthworms. The highest values are usually found in fertilized pastures and the lowest ones are in acid or arid soils $[12,57]$.

Taxonomic study was carried out on a total of 594 adult worms. The taxonomic key and nomenclature quoted by Rougerie et al. [18] allowed classification of 7 species of Lumbricidae: Aporrectodea trapezoides (Dugés, 1828), Aporrectodea rosea (Savigny, 1826), Aporrectodea caliginosa (Savigny, 1826), Allolobophora molleri (Rosa, 1889), Octodrilus complanatus (Dugés, 1828), Eiseniella tetraedra tetraedra (Savigny, 1826), and Proctodrilus antipai antipai (Michaelsen, 1891). Percentage of overall specific abundance shows dominance of Aporrectodea trapezoides, followed by Aporrectodea rosea (Figure 8).

Ap. trapezoides is present in greater quantity (13.4 individuals $/ \mathrm{m}^{2}$ ) in $\mathrm{S} 7$ characterized by nonpractical plowing and natural vegetation at Kochbi edge where there is healthy natural water (Figure 9). However, Ap. rosea is present in greater amounts (13.0 and 12.0 individuals $/ \mathrm{m}^{2}$ ) in S4 and $\mathrm{S} 5$ at edges of effluent and irrigated by wastewaters upstream. Pr. antipai is the most dominant species in S6, characterized by wastewater irrigation upstream of the effluent and arboriculture. On biomass, Ap. trapezoides is highest $\left(12.48 \mathrm{~g} / \mathrm{m}^{2}\right)$ in S7 at edges of natural water effluent. Ap. rosea is present on a biomass of $11.7 \mathrm{~g} / \mathrm{m}^{2}$ in $\mathrm{S} 5$ irrigated by wastewaters and characterized by cereal cultivation. These results allow us to deduce that wastewaters have intense effect on development of earthworm's biodiversity. Species Ap. rosea was the most concerned by this improvement.

Bazri et al. [17] noted in their study that it is curious and hard to explain that Ap.trapezoides, the most common and 


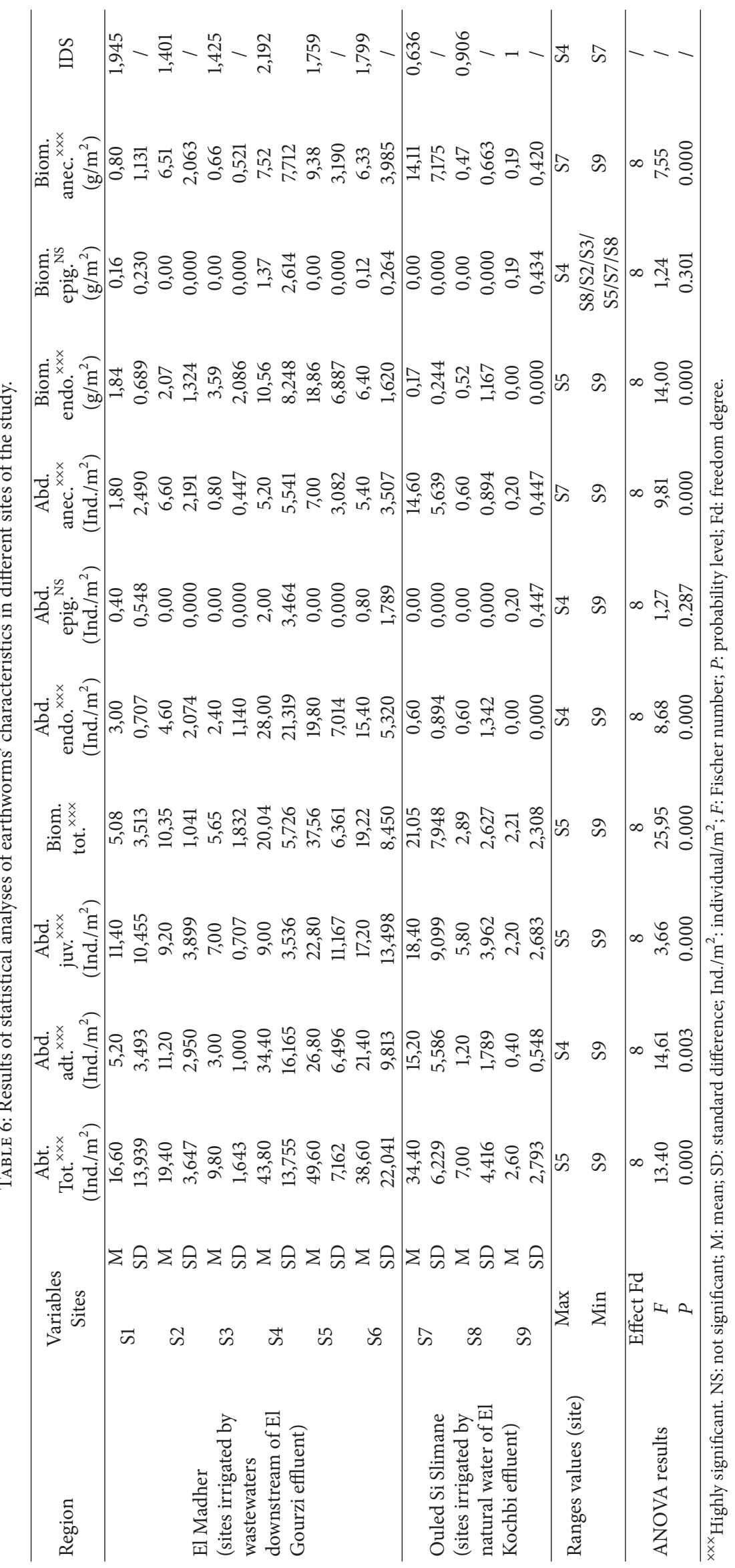




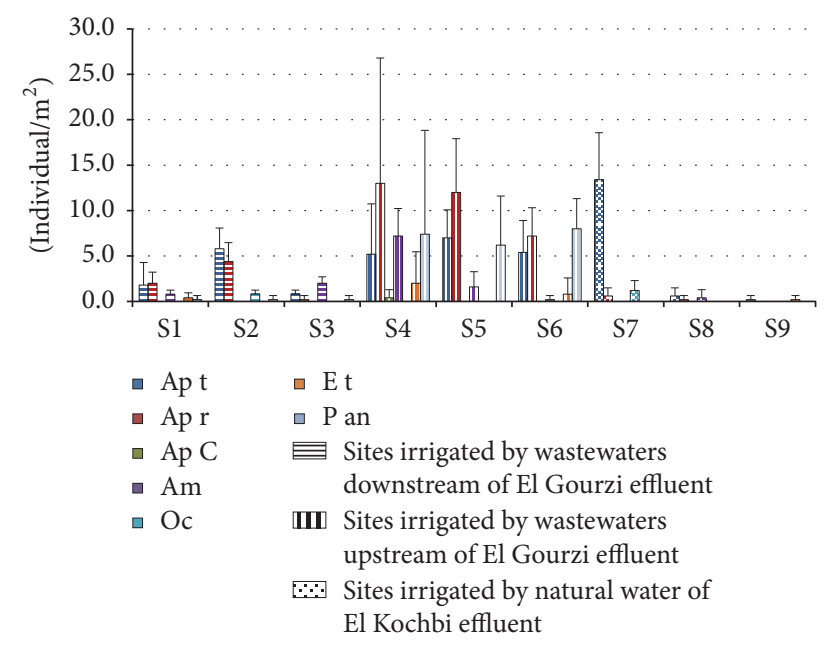

FIGURE 9: Earthworms' specific abundance average in study sites.

dominant species, was not previously quoted by other authors working on Algerian lumbricoid fauna. Possible explanations include identification problems in this complex group of species, recent introduction and posterior expansion, or older introduction as suggested by the large geographic distribution of the species. In the semiarid regions, the taxon A. molleri is important; it locates preferentially in wet points (notably at the edge of effluents). In mountains of semiarid regions, the species O. complanatus dominates. As for Ap. rosea, it is the only one observed in arid bioclimatic stage at points where there is sufficient water.

Among the 7 species inventoried (Figure 10), the endogeic species accounted for 62\% (Ap. rosea, A. molleri, P. antipai, and Ap. caliginosa), epigeic species for 3\% (E. tetrae$d r a$ ), and anecic species for $22 \%$ (O. complanatus and Ap. trapezoides); the latter may be considered as anecic, endogeic, or endoanecic because it varies according to the strain.

Bouché [10] separated earthworms into three categories, based on morphological and behavioral characteristics. Epigeic species are consumer litter living and feeding on or surface soil. Anecic earthworms live in permanent vertical burrows within the soil and may emerge to feed on surface layer; endogeic species live in temporary horizontal burrows and feed on the soil. This species is geophagous, since it gains its nutrients by eating the soil and the green morph is characterized by Bouché [10] as more epigeic.

Endogeic abundance is much higher in S4 at edges upstream of the El Gourzi effluent, which is without cultural practices (Figure 11). However, S7 at edges of El Kochbi effluent from natural waters, without cultural practices, is better represented by an anecic population. The epigeic population is important only on S4 and S6 upstream of the wastewater effluent. Endogeic earthworms are a major component of soil fauna communities in most natural ecosystems of the humid tropics [58].

The Shannon diversity index of different study sites is the lowest at S7 corresponding to edges of Kochbi effluent. It is the highest at $\mathrm{S} 4$ characterized by wastewaters upstream of El Gourzi effluent and any cultural practices. This result allows

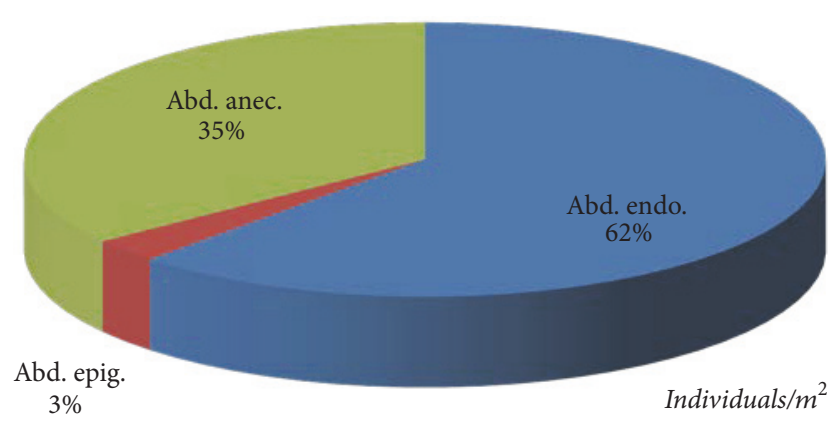

FIGURE 10: Earthworms' ecologic categories: abundance average.

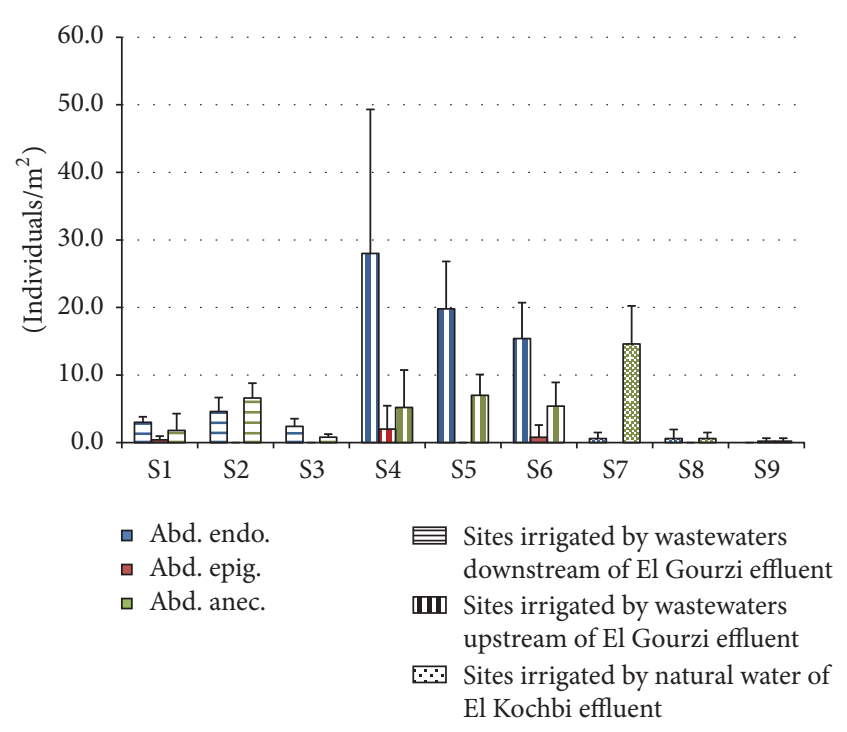

FIGURE 11: Earthworms' ecologic categories: abundance in studied soil sites.

us to deduce that wastewater loaded with organic matter promotes considerably the inheritance of the population of earthworms.

3.3. ANOVA. Statistical analysis with the Newman-Keuls multiple comparison posttest at $P \leq 0,05 \%$ (Table 5) revealed a highly significant effect of different irrigation practices and cultural practices on soil's physical parameters (Is, $\mathrm{Cr}, P \%$, $K 0.05, K 0.3, K 0.6$, and $K 1)$. Water retention, infiltration, and hydraulic conductivity are among the soil's hydraulic properties affected by soil porosity and pore size distribution $[40,59]$. Spatial variability of soil's physical properties within or among agricultural fields is inherent in nature due to geologic and pedologic soil forming factors, but some of the variability may be induced by tillage and other management practices. These factors interact with each other across spatial and temporal scales and are further modified locally by erosion and deposition processes [60]. In the regions with a cool climate, soils are exposed to freeze-thaw cycles, especially in the spring period. Aggregation and therefore soil structure may be either positively or negatively affected by freeze-thaw cycles [61]. Therefore, the impacts of wastewater 


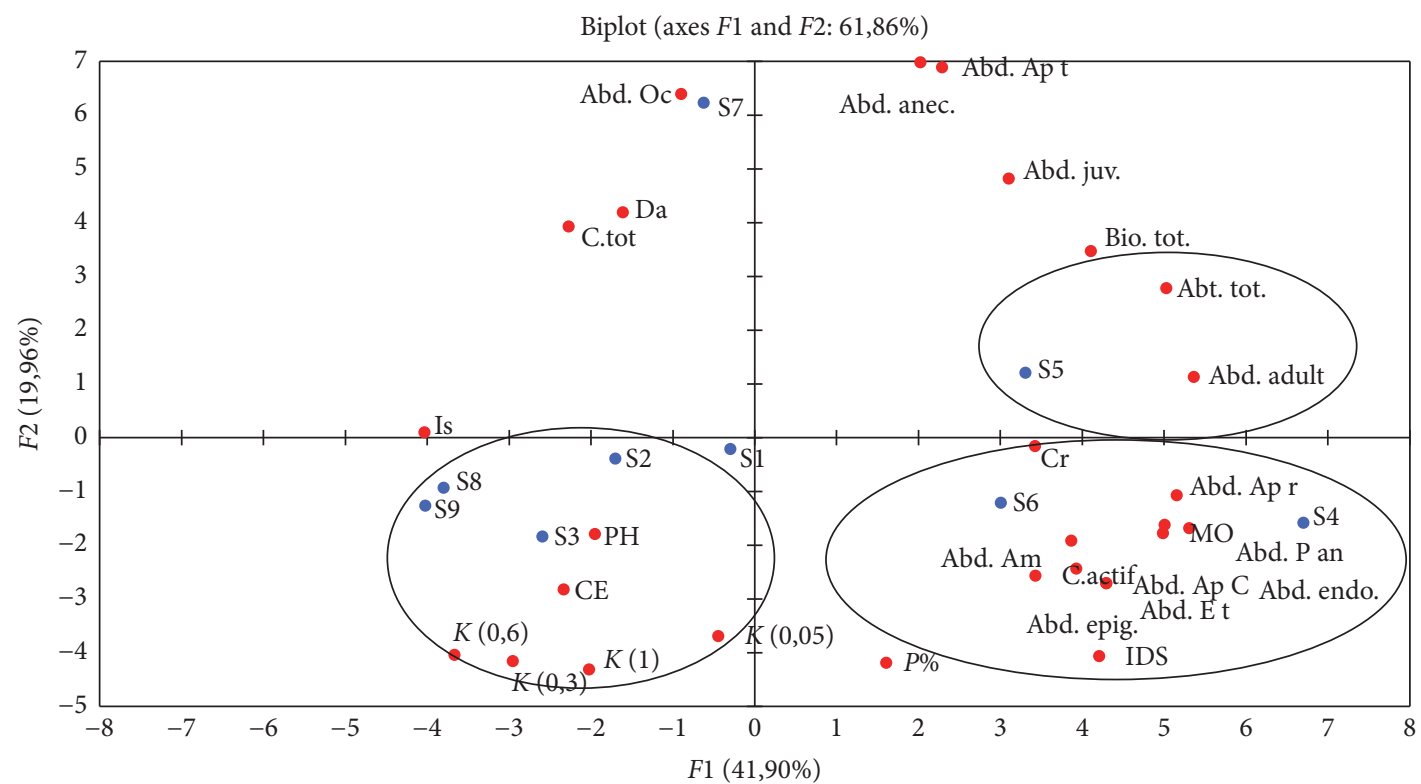

FIGURE 12: PCA graph of interaction between studied soil properties.

irrigation on main soil properties in agricultural areas under cool climate conditions may be different.

ANOVA reveals highlight at very highly significant effect of different irrigation practices and cultural practices on studied chemical parameters of soil ( $\mathrm{MO}, \mathrm{CE}, \mathrm{CaCO}_{3}$ tot., $\mathrm{CaCO}_{3}$ act., and $\mathrm{pH}$ ). Effectively, the soil's physical properties are associated with nutrient applied and environmental soil science availability, solute and pollutant movement, microbial activity, and soil organic matter stabilization [62].

On parameters of earthworm characteristics (Table 6), ANOVA revealed a significant effect of study sites differences except for Ap. caliginosa and E. tetraedra tetraedra species' abundance. The significant effect of sites has been well revealed on endogeic and anecic abundance. However, there is no significant effect of different irrigation and cropping practices on epigeic abundance.

3.4. PCA. In order to study interaction between physicochemical soil parameters and earthworm communities of studied sites, Principal Component Analysis (PCA) was used. This procedure makes it possible to group or distribute the sampling sites around principal axes in function of the physicochemical and earthworm parameters, thus facilitating observation of possible links between variables and places where they are most represented (Figure 12).

Contribution of principal axes to total variation is $41.90 \%$ for axis 1 and $19.96 \%$ for axis 2, which makes a total of $61.86 \%$, which is well acceptable. On variables distribution graph, both axes, 1 and 2, contrast two groups of variables: biological parameters of earthworms (total biomass, total abundance, and adult worms' abundance) and physical infiltration parameters (infiltration at saturation, $K 0.05 \mathrm{kPa}, K$ $0.3 \mathrm{kPa}, K 0.6 \mathrm{kPa}$, and $K 1 \mathrm{kPa}$ ). The first group of biological variables is represented by $\mathrm{S} 5$ site, characterized by irrigations with wastewaters upstream of El Gourzi effluent and by cereal crop (wheat/alfalfa). The group of infiltration characteristics is represented by S2 and S3 sites. These sites are irrigated with downstream wastewaters and characterized by cereal and arboreal crops. This group includes physicochemical characteristics: $\mathrm{pH}$ and EC. Axis 1 is intensely correlated with structural stability index and water retention capacity. It divides the characteristics of earthworms studied into two subgroups. One of them is well represented by S4 and S6 with irrigation by wastewater at upstream. This group includes $\mathrm{OM}$ and active $\mathrm{CaCO}_{3}$ as well as Shannon Biodiversity Index.

Francis and Fraser [63] and Capowiez et al. [64] reported that galleries excavated by terrestrial bioturbation activity contributed to water transfers. Also, Bottinelli et al. [65] and Pérès et al. [66] reported that earthworms contribute to improving soil porosity. Indeed, the PCA groups the S4, S5, and S6 sites with abundance and biomass of earthworms and soil porosity. For his part, Supersperg [67] found that annual applications of liquid sludge cause an increase in compactness of a heavy soil by clogging and a decrease in pores volume.

By this PCA, it can be deduced that very high organic charge of partially treated waters has negative repercussions on hydraulic conductivity if this load exceeds certain doses, because the PCA rallied the hydraulic conductivity at saturation by different pressures applied to S1, S2, and S3 sites downstream of El Gourzi effluent, as well as S8 and S9 sites irrigated with natural waters of El Kochbi effluent. This is contradictory to the results of Minhas and Samra [68] and Ababsa et al. [69] who have worked on the effect of earthworms on hydraulic conductivity in soils irrigated by wastewaters. Meanwhile, our findings concur with the works of some authors, Wang et al., Viviani and Iovino, and Molahoseini [40, 46, 70], who have to work on the same axis of research.

This opposition of results can be explained by more or less rapid duration of organic matter evolution of wastewaters. 
This change in state of $\mathrm{OM}$ from pores plugging form to soil stabilizing and structuring form is closely related to soil physicochemical parameters ( $\mathrm{pH}$, active $\mathrm{CaCO}_{3} \%$, and $\mathrm{EC}$ ). Indeed, Callot and Dupuis [71] assume the role of active $\mathrm{CaCO}_{3} \%$ in protection and conservation of organic matter in carbonate soils. Active $\mathrm{CaCO}_{3} \%$ thus acts as a protector against biological degradation of organic matter of these soils to make it a stable phase not sensitive to decomposition [72]. All the soils being studied are carbonate soils; their active $\mathrm{CaCO}_{3} \%$ should play an important role in humification process by rapidly sequestering lignified organic compounds as inherited or residual humus [28].

\section{Conclusion}

Our objective was to study interaction between earthworm community characteristics and physicochemical properties of soils characterized by irrigation with wastewaters and well waters in conditions of different topography (upstream and downstream) and cropping practices (natural vegetation, cereal cultivation, and arboriculture) in two regions of Batna department.

The results show that the maximum water retention capacity is better explained by the fine texture of the soil at the effluent border. The porosity and rates of infiltration at saturation are higher in sites characterized by irrigation with wastewaters downstream of effluent. This was explained by clogging of soil pores by suspended materials present in the wastewaters. However, structural stability is better in site characterized by irrigation with wastewaters upstream of El Gourzi effluent and cereal crop. This is due, on one hand, to input of organic matter and calcium ions which play the role of cements and cause improvement of particles soil aggregation according to Kirkham [42]. On the other hand, at cereal crop, that effect increases production of cementing substances through microbial activity by fungal and actinomycete mycelia that provide substrates to stabilize soil aggregates according to Miller and Kemper [43].

The $\mathrm{pH}$ levels are more alkaline in downstream sites than upstream sites of wastewater effluent. The $\mathrm{pH}$ of soils irrigated with wastewater decreases following oxidation of organic compounds and nitrification of ammonium. Electrical conductivity values are the lowest at sampling points of site, characterized by irrigation with wastewater upstream of El Gourzi effluent and cereal crop. This could probably be due to the level of organic matter which acts as a buffer. The organic matter is highest at site upstream of El Gourzi effluent border characterized by natural vegetation, which is certainly explained by an important load of organic matter from the wastewater upstream of the effluent, and high clay content of soil may physically protect the OM from the decomposition. The average percentage rate of total $\mathrm{CaCO}_{3} \%$ is higher at Kochbi natural water effluent border, while it showed low values at downstream sites. However, the active $\mathrm{CaCO}_{3} \%$ rate is the lowest at downstream site of El Gourzi effluent border. But it presents the highest values at S6 site irrigated by wastewaters upstream of effluent. This result appears to be related to soil $\mathrm{pH}$.
The total abundance and biomass average of earthworms at different sampling points of study sites are the lowest at site irrigated by natural waters of El Kochbi effluent which is cultivated by cereal. On the contrary, they are the highest at upstream site irrigated by El Gourzi wastewater and cereal growing. This result explains that abundance and biomass of earthworms are related to wastewaters irrigation. Earthworms are much more present where irrigation water is heavily loaded with organic materials.

Taxonomic study allowed classification of 7 species of Lumbricidae. Percentage of overall specific abundance shows dominance of Aporrectodea trapezoides, followed by Aporrectodea rosea. The result shows that wastewaters have intense effect on development of earthworm's biodiversity. Species Ap. rosea was the most concerned by this improvement. Among the 7 species inventoried, the endogeic earthworms represent the majority. Endogeic abundance is much higher in site at edges upstream of the El Gourzi effluent, which is without cultural practices. However, site at edges of El Kochbi effluent from natural waters, without cultural practices, is better represented by an anecic population. The Shannon diversity index of different study sites shows that wastewater promotes considerably the inheritance of the population of earthworms.

ANOVA revealed a highly significant effect of different irrigation types as well as different cultivation practices on all physicochemical properties of soil and on endogeic and anecic population. This was not the case for the epigeic population.

The PCA allowed characterizing two major groups. The first group is defined by sites that are explained by the hydrodynamic infiltration. These sites are irrigated by wastewater; they are located downstream of effluent (lowest load of organic matter) and characterized by cereal and arboreal crops. This group includes other chemical characteristics: $\mathrm{pH}$ and EC. The second group formed by upstream sites irrigated by wastewaters encompasses the characteristics of earthworms explained by highest load of organic matter. It includes chemical characteristics: OM and active limestone. It also includes the Shannon Biodiversity Index. We explained this by active $\mathrm{CaCO}_{3} \%$, which acts as a protector against biological degradation of organic matter of these soils to make it a stable phase not sensitive to decomposition.

Overall, the results of the PCA show us that the effect of wastewater is positive on improvement of abundance and biomass and biodiversity of earthworms population. On the contrary, the wastewaters are unfavorable for the infiltration physical parameters of water into soil. This will surely have long-term repercussions on the physical and biological parameters of soil and will induce a new organization of macro- and mesoporosity due to improvement of biological parameters of earthworms.

Finally, we propose complementing these results in the field and in the laboratory to see the evolution of infiltration parameters of soil water in parallel with the dynamics of earthworm community in soil irrigated by wastewaters. The biodiversity of earthworms may induce an improvement in infiltration and reduce the problems of clogging pores and 
solve other problems that wastewaters can introduce into soils.

\begin{tabular}{ll} 
Abbreviations \\
Cr: & Water retention capacity \\
Is: & Structural instability index \\
Da: & Bulk density \\
P: & Porosity \\
K (h) sat.: & Saturated hydraulic conductivity at \\
& potential difference \\
CE: & Electric conductivity \\
MO: & Organic matter \\
TEM: & Trace Element Metals \\
MES: & Suspended matter \\
BOD5: & 5-Day biological oxygen demand \\
COD: & Chemical oxygen demand \\
Abd: & Abundance \\
Juv.: & Juvenile \\
Adt.: & Adult \\
Biom.: & Biomass \\
Endo.: & Endogeic \\
Epig.: & Epigeic \\
Anec.: & Anecic \\
Ap t: & Aporrectodea trapezoides \\
Ap r: & Aporrectodea rosea \\
Ap c: & Aporrectodea caliginosa \\
Am: & Allolobophora molleri \\
P ant: & Proctodrilus antipai antipai \\
Oc: & Octodrilus complanatus \\
E t: & Eiseniella tetraedra tetraedra \\
SDI: & Shannon Biodiversity Index \\
Dj: & Djebel or mountain \\
Wed: & effluent. \\
& \\
\hline
\end{tabular}

\section{Conflicts of Interest}

The authors declare that there are no conflicts of interest regarding the publication of this paper.

\section{References}

[1] E. Corcoran, C. Nellemann, E. Baker, R. Bos, D. Osborn, and H. Savelli, ick Water? The central role of wastewater management in sustainable development. A rapid response assessment, United Nations Environment Programme, UN-HABITAT, Arendal, Norway, 2010.

[2] F. Hiouani, H. Messadia, A. Masmoudi, D. Madani, and C. Tir, "Influence des eaux résiduaires de tannerie sur le poids de la matière sèche," in Proceedings of the Revue des Régions Arides -Actes du 4ème Meeting International - Numéro Spécial -, n॰35 (3/2014), pp. 1023-1319, 2013.

[3] B. Jimenez and T. Asano, "Water reclamation and reuse around the World," in Water Reuse: An International Survey of Current Practice, Issues and Needs, pp. 3-26, IWA Publishing, London, UK, 2008.

[4] Z. S. Burak, "Water, wetlands and climate change: buildings linkages for their integrated management," Mediterranean Regional Roundtable, pp. 10-11, 2002.

[5] H. Bouzerzour, L. Tamrabet, and M. Kribaa, "Réponse de deux graminées fourragères, l’orge et l'avoine, aux apports d'eau usée et de boue résiduaire," in Proceedings Séminaire International: Biologie et Environnement, 71, Univ. Mentouri, Constantine, Algeria, 2002.

[6] L. Tamrabet, H. Bouzerzour, M. Kribaa et, and D. Golea, "Le devenir des eaux usées traitées: Réponse de deux graminées fourragères, l'orge et l'avoine, aux apports d'eau usée traitée," in Proceedings of the Actes du Colloque international Oasis, Eau et Population, Université Khider, Biskra, Algérie, 2003.

[7] M. B. Pescod, Wastewater Treatment and Use in Agriculture, FAO Irrigation and Drainage, Rome, Italy, 1992.

[8] A. Coppola, A. Santini, P. Botti, S. Vacca, V. Comegna, and G. Severino, "Methodological approach for evaluating the response of soil hydrological behavior to irrigation with treated municipal wastewater," Journal of Hydrology, vol. 292, no. 1-4, pp. 114-134, 2004.

[9] I. Nadav, J. Tarchitzky, and Y. Chen, "Water repellency induced by organic matter (OM) in treated wastewater (TWW) infiltration ponds and irrigation," Functions of Natural Organic Matter in Changing Environment, pp. 883-887, 2013.

[10] M. B. Bouché, Lombriciens de France: Ecologie et Systématique. INRA. Publication 72-2, Institut national de la recherche agronomique, Paris, France, 1972.

[11] G. Bachelier, "Les vers annelés," in La faune du sol, IDT n॰38, pp. 127-183, ORSTOM, Paris, France, 1978.

[12] K. E. Lee, Earthworms: Their Ecology and Relationship with Soils and Land Use, Academic Press, Sydney, Australia, 1985.

[13] P. Lavelle, C. Lattaud, D. Trigo, and I. Barois, "Mutualism and biodiversity in soils," Plant and Soil, vol. 170, no. 1, pp. 23-33, 1995.

[14] T. Kautz, C. Stumm, R. Kösters, and U. Köpke, "Effects of perennial fodder crops on soil structure in agricultural headlands," Journal of Plant Nutrition and Soil Science, vol. 173, no. 4, pp. 490-501, 2010.

[15] L. A. Schipper, J. C. Williamson, H. A. Kettles, and T. W. Speir, "Impact of land-applied tertiary-treated effluent on soil biochemical properties," Journal of Environmental Quality, vol. 25, no. 5, pp. 1073-1077, 1996.

[16] A. Lemtiri, G. Colinet, T. Alabi et al., "Impacts of earthworms on soil components and dynamics. A review," Biotechnology, Agronomy and Society and Environment, vol. 18, no. 1, pp. 121133, 2014.

[17] K. Bazri, G. Ouahrani, Z. Gheribi-Aoulmi et, D. J, and D. Cosin, "La diversité des lombriciens dans l'est algérien depuis la côte jusqu'au désert," Ecologia Mediterranea, vol. 39, no. 2, p. 17, 2013.

[18] R. Rougerie, T. Decaëns, L. Deharveng et al., "DNA barcodes for soil animal taxonomy," Pesquisa Agropecuaria Brasileira, vol. 44, no. 8, pp. 789-802, 2009.

[19] T. Decaëns, "Macroecological patterns in soil communities," Global Ecology and Biogeography, vol. 19, no. 3, pp. 287-302, 2010.

[20] L. Tamrabet, M. Kribaa, B. Hamidi, S. Alalata, W. Berkani, and A. Hamdoudi, "Evaluation de l'aptitude des effluents d'Oued El Gourzi (Batna, Nord Est d'Algérie) à l'irrigation et leur impact sur le sol et la qualité des cultures maraîchères et fourragères," in Actes du congrès international 'Eau et Déchets, Université Mohamed I, Oujda, Maroco, 2007.

[21] Office National de l'Assainissement (ONA) Situation actuelle des stations de traitement d'eaux usées en Algérie. MRE. Alger, Algérie. 7 p. 2006.

[22] S. Maalem and N. Ghanem, "La caractérisation physico-chimiques des eaux usées de Oued El Gourzi," In Actes de Colloque National de Biologie de l'université de Batna, 2016. 
[23] M. Bournaud and C. Amoros, "Des indicateurs biologiques aux descripteurs de fonctionnement: Quelques exemples dans le système fluvial," Bull. Ecol, vol. 15, no. 1, pp. 57-66, 1984.

[24] H. Marschner, Mineral Nutrition of Higher Plants, vol. 78, Academic press, New York, NY, USA, 2nd edition, 1995.

[25] Z. Alouni, "Flux de la charge parasitaire dans cinq stations d'épuration en Tunisie," Revue des sciences de l'eau, vol. 6, no. 4, pp. 453-462, 1993.

[26] A. Mussy et and M. Soutter, Physique du sol, IS.BN., 1st edition, 1991.

[27] D. Baize, Guide des analyses courantes en pédologie, INRR, 1988.

[28] P. Duchaufour, Pédologie: I. Pédogenèse et classification, Masson, Paris, France, 1977.

[29] B. Blakemore, Cosmopolitan Earthworms, An Eco-Taxonomic Guide to the Peregrine Species of the World, 2nd Ed., 656 p., 2007.

[30] M. B. Bouché, "Stratégies Lombriciennes, Soil organism as components of ecosystems," in Proceedings of the 6th Int. Coll. Soil Zool. Ecol. Bull., U. Lohm and T. Persson, Eds., pp. 122-132, Stockholm, Sweden, 1977.

[31] K. Bazri, "Etude de la biodiversité des lombriciens et leurs relations avec les propriétés du sol dans différents étages bioclimatiques, dans l'Est Algérien," in Thèse doctorat, p. 188, Constantine University, 2015.

[32] J. Blondel, Biogéographie et écologie, Masson, Paris, France, 1979.

[33] R. Dajoz, Précis d'écologie, vol. 505, Dunod, Paris, France, 1985.

[34] R. Dajoz, Précis d'écologie, vol. 434, Dunod, Paris, France, 1975.

[35] M. A. Mojid and G. C. L. Wyseure, "Implications of municipal wastewater irrigation on soil health from a study in Bangladesh," Soil Use and Management, vol. 29, no. 3, pp. 384-396, 2013.

[36] M. A. Gharaibeh, T. A. Ghezzehei, A. A. Albalasmeh, and M. Z. Alghzawi, "Alteration of physical and chemical characteristics of clayey soils by irrigation with treated waste water," Geoderma, vol. 276, pp. 33-40, 2016.

[37] A. Mojiri, "Effects of municipal wastewater on physical and chemical properties of saline soil," Journal of Biodiversity and Environmental Sciences, vol. 5, pp. 71-76, 2011.

[38] I. Vogeler, "Effect of long-term wastewater application on physical soil properties," Water, Air, and Soil Pollution, vol. 196, no. 1-4, pp. 385-392, 2009.

[39] J. Tarchitzky and Y. Chen, "Rheology of sodium-montmorillonite suspensions: Effects of humic substances and $\mathrm{pH}$," Soil Science Society of America Journal, vol. 66, no. 2, pp. 406-412, 2002.

[40] Z. Wang, A. C. Chang, L. Wu, and D. Crowley, "Assessing the soil quality of long-term reclaimed wastewater-irrigated cropland," Geoderma, vol. 114, no. 3-4, pp. 261-278, 2003.

[41] A. Kunhikrishnan, N. S. Bolan, K. Müller, S. Laurenson, R. Naidu, and W.-I. Kim, "The influence of wastewater irrigation on the transformation and bioavailability of heavy metal(loid)s in soil," Advances in Agronomy, vol. 115, pp. 215-297, 2012.

[42] B. Kirkham, Isposal of sludge on land; Effects on soils plants and ground water compost, Sc., pp. 6-10, 1974.

[43] D. E. Miller and W. D. Kemper, "Water stability of aggregates of two soils as in fluenced by incorporation of alfalfa," Agron. J, vol. 54, no. 6, pp. 494-496, 1962.

[44] S. M. F. Rabbi, B. R. Roy, M. M. Miah, M. S. Amin, and T. Khandakar, "Spatial variability of physical soil quality index of an agricultural field," Applied and Environmental Soil Science, vol. 2014, Article ID 379012, 10 pages, 2014.
[45] G. Bardhan, D. Russo, D. Goldstein, and G. J. Levy, "Changes in the hydraulic properties of a clay soil under long-term irrigation with treated wastewater," Geoderma, vol. 264, pp. 1-9, 2016.

[46] G. Viviani and M. Iovino, "Wastewater reuse effects on soil hydraulic conductivity," Journal of Irrigation and Drainage Engineering, vol. 130, no. 6, pp. 476-484, 2004.

[47] J. L. Morel, A. Guikart, and H. Sedgo, "Effet de l'épandage des boues urbaines sur l'état physique des sols communs," in XI congrès de l'A.I.S.S. Ed, 1A. I. S. S. XI congrФs de, Ed., pp. 1219, Canada, Mouton, Canada, 1978.

[48] U. Sahin, O. Anapali, and S. Ercisli, "Physico-chemical and physical properties of some substrates used in horticulture," Gartenbau wissen schaft 67, pp. 55-60, 2002.

[49] M. J. Mohammad and N. Mazahreh, "Changes in soil fertility parameters in response to irrigation of forage crops with secondary treated wastewater," Communications in Soil Science and Plant Analysis, vol. 34, no. 9-10, pp. 1281-1294, 2003.

[50] O. Vazquez-Montiel, N. J. Horan, and D. D. Mara, "Management of domestic wastewater for reuse in irrigation," Water Science and Technology, vol. 33, no. 10-11, pp. 355-362, 1996.

[51] A. R. Hayes, C. F. Mancino, and I. L. Pepper, "Irrigation of Turfgrass with Secondary Sewage Effluent: I. Soil and Leachate Water Quality," Agronomy Journal, vol. 82, no. 5, p. 939, 1990.

[52] K. El Oumlouki, R. Moussadek, A. Zouahri, H. Dakak, M. Chati, and M. El Amrani, "Study of physic-chemical quality of water and soil in the region Souss Massa (Case perimeter Issen), Morocco," Journal of Materials and Environmental Science, vol. 5, pp. 2365-2374, 2014.

[53] M. Galavi, A. Jalali, M. Ramroodi, S. R. Mousavi, and H. Galavi, "Effects of Treated Municipal Wastewater on Soil Chemical Properties and Heavy Metal Uptake by Sorghum (sorghum bicolor L.)," Journal of Agricultural Science, vol. 2, no. 3, 2010.

[54] M. A. Gharaibeh, N. I. Eltaif, and B. Al-Abdullah, "Impact of field application of treated wastewater on hydraulic properties of vertisols," Water, Air, and Soil Pollution, vol. 184, no. 1-4, pp. 347-353, 2007.

[55] P. Omodeo and G. Martinucci, Earthworms of Maghreb, Selected Symposya and Monographs U.Z.I., 2, Mucchi, Modena, pp. 235-250, 1987.

[56] A. Edwards and P. J. Bohlen, Biology et Ecology of earthworms, vol. 3, Springer Science \& Business Media, 1996.

[57] P. Lavelle and A. V. Spain, Soil Ecology, Springer Science \& Business Media, 2001.

[58] P. Lavelle, G. Melendez, B. Pashanasi, and R. Schaefer, "Nitrogen mineralization and reorganization in casts of the geophagous tropical earthworm Pontoscolex corethrurus (Glossoscolecidae)," Biology and Fertility of Soils, vol. 14, no. 1, pp. 49-53, 1992.

[59] R. A. Gonçalves, T. V. Gloaguen, M. V. Folegatti, P. L. Libardi, Y. Lucas, and C. R. Montes, "Pore size distribution in soils irrigated with sodic water and wastewater," Revista Brasileira de Ciência do Solo, vol. 34, no. 3, pp. 701-707, 2010.

[60] J. Iqbal, J. A. Thomasson, J. N. Jenkins, P. R. Owens, and F. D. Whisler, "Spatial variability analysis of soil physical properties of alluvial soils," Soil Science Society of America Journal, vol. 69, no. 4, pp. 1338-1350, 2005.

[61] U. Sahin, I. Angin, and F. M. Kiziloglu, "Effect of freezing and thawing processes on some physical properties of saline-sodic soils mixed with sewage sludge or fly ash," Soil and Tillage Research, vol. 99, no. 2, pp. 254-260, 2008.

[62] R. Lal and M. K. Shukla, Principles of Soil Physics, Marcel Dekker, New York, NY, USA, 2004. 
[63] G. S. Francis and P. M. Fraser, "The effects of three earthworm species on soil macroporosity and hydraulic conductivity," Applied Soil Ecology, vol. 10, no. 1-2, pp. 11-19, 1998.

[64] Y. Capowiez, S. Cadoux, P. Bouchant et al., "The effect of tillage type and cropping system on earthworm communities, macroporosity and water infiltration," Soil and Tillage Research, vol. 105, no. 2, pp. 209-216, 2009.

[65] N. Bottinelli, T. Henry-des-Tureaux, V. Hallaire et al., "Earthworms accelerate soil porosity turnover under watering conditions," Geoderma, vol. 156, no. 1-2, pp. 43-47, 2010.

[66] G. Pérès, D. Cluzeau, P. Curmi, and V. Hallaire, "Earthworm activity and soil structure changes due to organic enrichments in vineyard systems," Biology and Fertility of Soils, vol. 27, no. 4, pp. 417-424, 1998.

[67] H. Supersperg, tilisation de la boue à l'état liquide sur les sols lourds. BERICHETE. Der A.TV., 28p.1977.

[68] P. S. Minhas and J. S. Samra, Wastewater use in peri-urban agriculture: impacts and opportunities, Central Soil salinity Research Institute, Karnal 132001, India, Tech. Bull., N56,2; p., 2004.

[69] N. Ababsa, M. Kribaa, D. Addad, L. Tamrabet, and M. Baha, "Does earthworms density really modify soil's hydrodynamic properties in irrigated systems with recycled water?" Journal of Fundamental and Applied Sciences, vol. 8, no. 2, p. 627, 2016.

[70] H. Molahoseini, "Long-term effects of municipal wastewater irrigation on some properties of a semiarid region soil of Iran," International Journal of Science, Engineering and Technology, vol. 3, no. 4, pp. 444-449, 2014.

[71] G. Callot and M. Dupuis, "Le calcaire actif des sols et sa signification," Science du sol, vol. 1, pp. 17-27, 1980.

[72] H. Ben Hassine, T. Aloui, T. Gallali, T. Bouzid, S. El amri, and R. Ben Hassen, "Valuation quantitative et rôles de la matière organique dans les sols cultivés en zones subhumides et semiarides méditerranéennes de la Tunisie," Agro-Solutions, vol. 17, no. 2, pp. 4-17, 2008. 

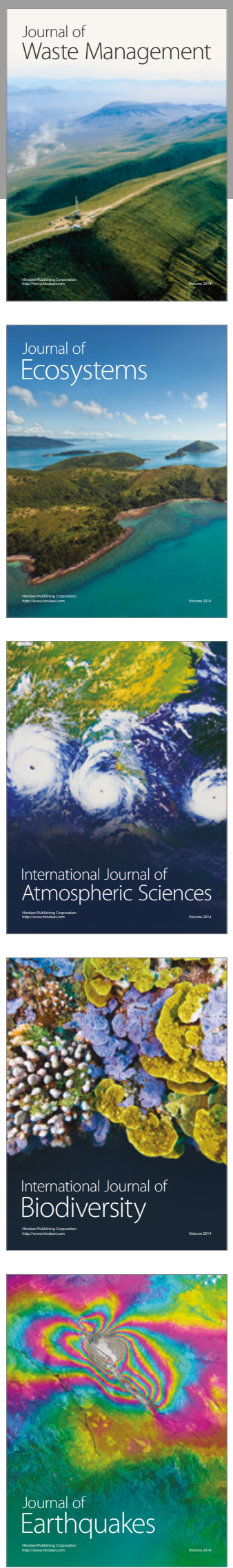
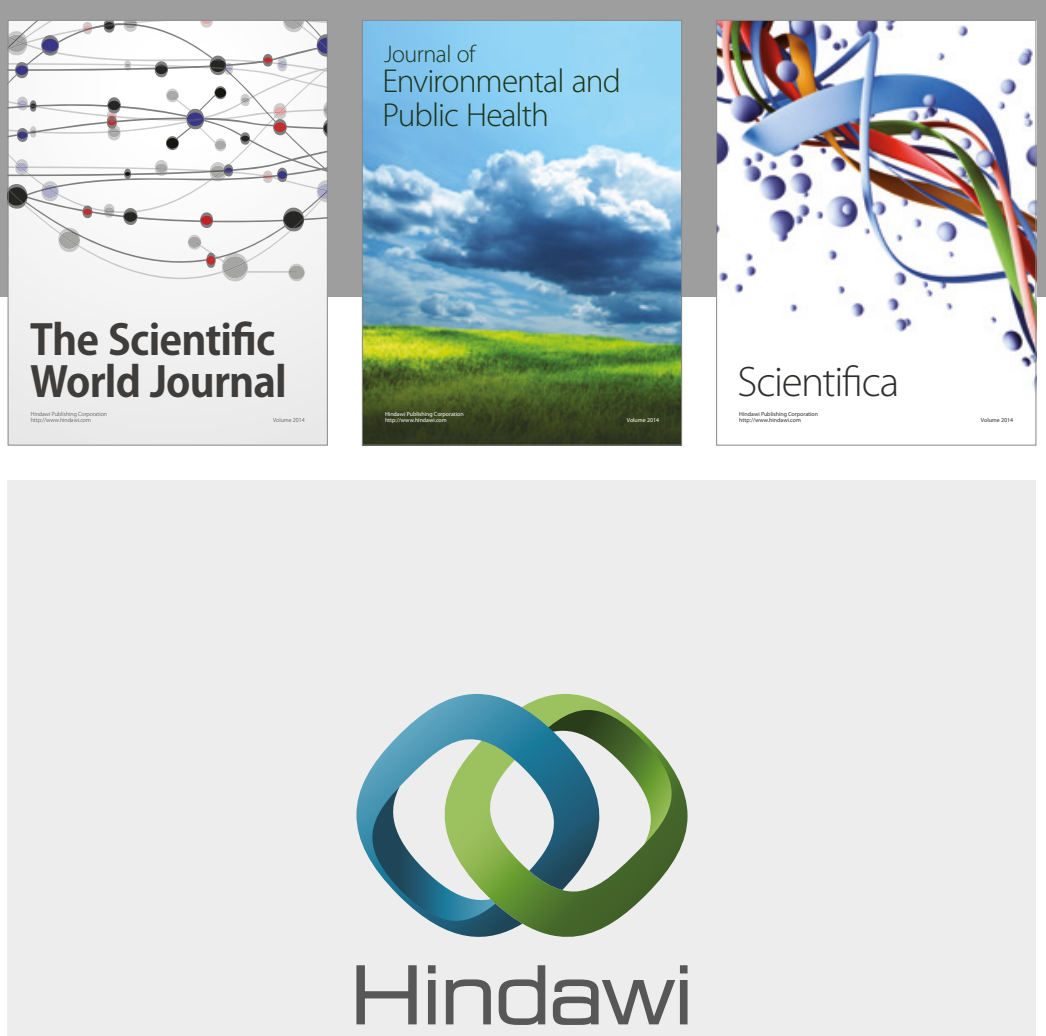

Submit your manuscripts at

https://www.hindawi.com
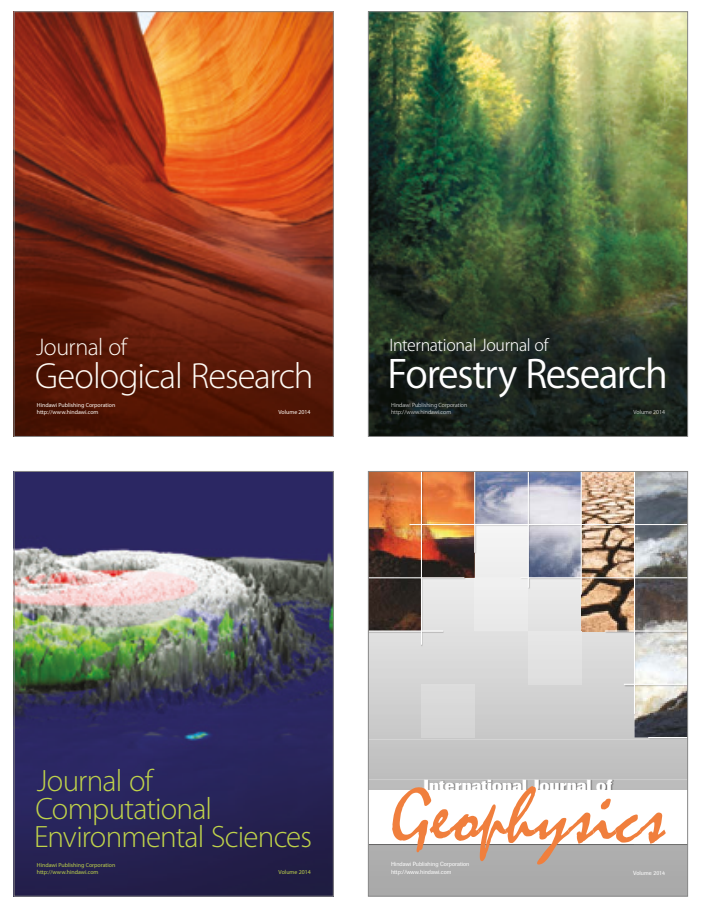
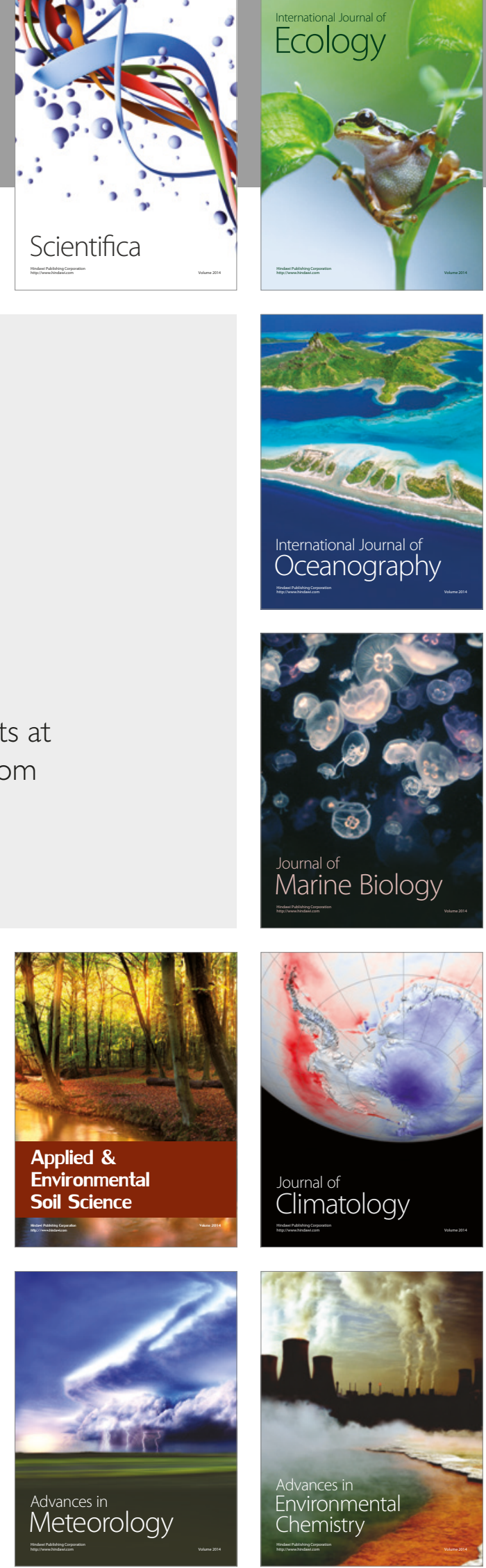